\title{
Dakwah Wasathiyah Al-Islam Melalui Penyuluh Agama Islam di Kota Surakarta
}

\author{
Arif Yudi Asmara; \\ UIN Raden Mas Said Surakarta; \\ Surakarta, Indonesia; \\ asmoroarif189@gmail.com;
}

\begin{abstract}
The concept of wasathiyah al-Islam is an important concept for the Islamic world today. Especially for the development of the da'wah method which metamorphosed into Da'wah wasathiyah al-Islam. Understanding Da'wah wasathiyyah al-Islam: 'is (justice), at-tawazun (balance), and tasamuh (tolerant) in religion is the responsibility of Islamic da'wah, including Islamic Religious Counselors, especially in Surakarta City. Functional Islamic Religious Extension is the main task to provide guidance or counseling and development in the language of religion. Surakarta is a barometer of various religious sects and schools ranging from radicalism, Wahhabism, liberalism is a challenge for Islamic Religious Extension, especially during this Covid 19 pandemic. Wasathiyah da'wah plays an active role in changing the mindset of the target group in responding to differences from one another, such as not highlighting differences in carrying out religious teachings, conducting joint recitations, and carrying out religious activities together, are indicators of the success of wasathiyah al-Islam da'wah

Konsep Wasathiyah Al-Islam merupakan konsep yang sangat penting bagi dunia Islam saat ini. Terlebih untuk pengembangan metode dakwah yang bermetamorfosis menjadi Dakwah Wasathiyah Al-Islam. Memahami Dakwahwasathiyyah al-Islam: 'adalah (keadilan), attawazun (keseimbangan) dan tasamuh (toleran) dalam beragama merupakan tanggung jawab dakwah Islam, termasuk Penyuluh Agama Islam khususnya di Kota Surakarta. Penyuluh Agama Islam secara fungsi merupakan sebuah tugas pokok untuk melakukan bimbingan atau penyuluhan dan pembangunan dalam bahasa agama. Surakarta merupakan barometer dari berbagai aliran dan mazhab beragama mulai radikalisme, wahabisme, liberalismemerupakan sebuah tantangan bagi Penyuluh Agama Islam, terlebih dimasa pandemik Covid 19 ini. Dakwah wasathiyah berperan aktif dalam merubah mindset kelompok binaan dalam mensikapi perbedaan satu dengan lainnya seperti tidak menonjolkan perbedaan dalam melaksanakan ajaran agama, pengajian bersama dan melakukan kegiatan-kegiatan keagamaan secara bersama, merupakan indikator keberhasilan dakwah wasathiyah Al-Islam.
\end{abstract}




\section{A. Pendahuluan}

Indonesia adalah negara yang berpenduduk muslim terbesar di dunia yang kaya akan budaya, suku, bahasa dan agama ${ }^{1}$. Kemajemukan merupakan anugrah sekaligus kekuatan yang dimiliki bangsa Indonesia, baik kekuatan secara sosial, kekuatan dalam kebinekaan yang berbeda-beda tapi ada kekuatan untuk bersatu, yang sudah terpatri sejak nenek moyang bangsa ini ada. Pameo gotong royong yang didengungkan sejak berabad-abad lamanya merupakan embrio energi untuk kemajuan dan modal untuk membangun bangsa ini. Perbedaan yang satu dalam kemajemukan harus di kelola dengan baik dan tepat agar harmonisasi kehidupan dalam berbangsa dapat di nikmati oleh seluruh anak bangsa dan masyarakat luas, sehingga dapat menghindarkan adanya perbedaan yang mengarah pada sikap negatif, terlebih memicu konflik antar masyarakat yang bersifat destruktif. Hal inilah yang akan mencederai nilai kerukunan umat beragama dan berbangsa. Kasus yang telah terjadi di aceh, lampung, sampit, poso, ambon, NTB, merupakan contoh sekian banyak kasus yang harus segera di selesaikan dengan kepala dingin duduk bersama dalam wadah kebinekaan, sebab jika hal ini tidak segera di selesaikan akan membawa dampak yang negatif bagi kelangsungan harmonisasi kehidupan beragama, berbangsa dan bernegara.

Akhir-akhir ini kita dapati beberapa fenomena cara pandang beragama yang beragam dari umat Islam. Keberagaman tersebut dapat dilihat melalui beberapa kelompok Islam dari berbagai paham keagamaan yang ada dalam Islam. Kelompok pertama adalah kelompok paham Islam garis keras, kelompok ini memiliki sifat yang kaku dalam memahami teks agama, serta memiliki sikap intoleran terhadap pemeluk agama lain, mengkafirkan terhadap sesama muslim, mudah tersulut dan mudah

\footnotetext{
${ }^{1}$ Martin Van Bruinessen, "Genealogies of Islamic Radicalism in post-Suharto Indonesia", Southeast Asia Research no 2, 2002, 117.
} 
melakukan kekerasan terhadap sesama kaum muslimin terlebih dengan orang yang berbeda agama. Kelompok kedua, adalah kelompok paham liberal, kelompok ini cenderung cuek serta lebih mengutamakan logika daripada wahyu Allah SWT. Sehingga muncul prilaku yang tidak sesuai norma masyarakat dan agama, semisal pernikahan sesama jenis, sholat dengan bahasa yang tidak sesuai rukun dan syarat sahnya sholat seperti apa yang di contohkan Rosulullah SAW. Kelompok liberal ini cenderung longgar dalam mengamalkan nilai-nilai Islam, membolehkan samen leaven (hidup serumah tanpa ikatan pernikahan) dan lain sebagainya.

Paham pemikiran kedua kelompok tersebut diatas sangat popular dalam pembahasan (diskusi) dan seminar di tingkat nasional maupun internasional tentang pemikiran Islam, namun bukanlah model yang ideal untuk dijadikan patokan dalam menjalankan praktek beragama secara Islam baik di Indonesia bahkan dunia. Praktek keberagamaan di Indonesia sudah teruji sejak bangsa ini berdiri. Di dalam prosesnya sering berbenturan dengan sejarah peradaban multikultur yang ada, sehingga hal ini membuat Islam Indonesia sangat dewasa dan merespon dengan baik setiap perkembangan pemikiran Islam yang ada, kecuali pemikiran dan paham Islam liberal dan paham Islam Radikal. Karena kedua paham tersebut tidak sesuai prinsip dan kepribadian bangsa Indonesia.

Kemunculan kedua paham kelompok tersebut di atas, tidak sedikitpun membawa kemaslahatan bagi Islam secara khusus, dan umat Islam secara keseluruhan. Bahkan sebaliknya membawa citra negatif Islam, di satu sisi Islam dianggap sebagai agama temperamen yang menyelesaikan permasalahan dengan kekerasan, di satu sisi Islam dianggap tidak konsisten dengan nilai Islamnya disebabkan oleh keberadaan sebagian umat yang longgar dalam praktek keagamaannya hingga menghilangkan identitas Islam yang sesungguhnya, karena larut dalam budaya liberalisme.

Kelompok-kelompok tersebut diatas telah kami indentifikasi bahwa terdapat indikasi dan kecenderungan sikap (tatharuf yamini) dan (yasari) terdapat pada paham kelompok-kelompok keagamaan yang berkembang di salah satu kecamatan 
di Kota Surakarta yaitu paham Salafi, Kelompok Jama'ah Tablig, paham minoritas syiah,dan paham liberalisme. Kelompok Salafi sejauh yang dapat kami identifikasi dalam kurun waktu 10 tahun terakhir dapat dikelompokkan menjadi 3, yaitu:

1) kelompok Salafi Jihady; kelompok ini sebagian besar berada pada ormas keagamaan (laskar Islam) yang dalam perannya mencoba memberikan solusi keumatan di tengah masyarakat muslim di surakarta (baca: Solo) dengan cenderung kepada sikap represif, hegemonis, destruktif dan idealis serta ketat dalam praktek beragama. Kelompok ini tak jauh beda dengan kelompok lain dalam membangun aqidah dan pemahaman, serta merekrut massa melalui dakwah majlis taklim. Kelompok ini termasuk dalam kelompok rumpun besar pada pemahaman Wahabi.

2) Kelompok Salafi Haraky; kelompok ini berbasis pada pemikiran dan pergerakan yang memberikan porsi pada penguatan lembaga dan organisasi massa, dakwah, majlis taklim, pendidikan formal, pengembangan wakaf, pengembangan wakaf tunai, kajian-kajian Islam yang merupakan metode dalam merekut massa. Secara legalitas, kelompok ini berbadan hukum dan memiliki visi dan misi yang jelas dan bergerak sesuai komando pimpinannya. Kelompok ini masuk dalam rumpun besar berpaham Wahabi.

3) Kelompok salafi Taklimi; Kelompok ini lebih cenderung pada penguatan lembaga pendidikan formal, semisal SDIT, majlis taklim, pengembangan pondok pesantren, dan wakaf. Kelompok ini sangat jauh berbeda dengan dua kelompok tersebut di atas, kelompok ini lebih lunak dan terbuka terhadap kebijakan pemerintah, tapi dalam praktek keagamaan (ubudiyah) jauh lebih ketat dari kedua kelompok diatas, tak heran pembahasan dan kajian tentang bid'ah di kelompok ini sangat kental sekali sehingga muncul sikap tabdi' (membid'ahkan), yaitu sikap menganggap kelompok lain salah dan menganggap kelompoknya paling benar. ${ }^{2}$

\footnotetext{
${ }^{2}$ Arif Yudi Asmara.S.Ag., M.SI “Makalah dan Jurnal Penelitian” hal.29
} 
Berdasarkan pada karakteristik dari 3 macam kelompok salafi diatas dapat kita gambarkan secara umum tentang keberagamaan umat Islam di Surakarta pada saat ini. Selain itu, juga terdapat kelompok lain yang juga mencoba melakukan penetrasi pada tiap kantong umat untuk menyebarkan faham aliran keagamaanya, sehingga tidak sedikit menimbulkan kegaduhan di tengah umat Islam itu sendiri. Kasus pemukulan dan pengeroyokan yang menyasar ke keluarga Habib Umar Assegaf oleh kelompok laskar jihad gabungan antara Surakarta dan Sukoharjo tersebut terjadi di tengah acara midodareni atau doa sebelum menjalankan akad Nikah di Jl. Cempaka No.81 Kampung Mertodranan Kelurahan Pasar Kliwon di Kecamatan Pasarkliwon. Kasus yang terjadi pada hari sabtu tanggal 08 Agustus 2020 tersebut berakhir setelah ditetapkannya 8 tersangka, dan kasus saat itu dalam penanganan pihak yang berwajib ${ }^{3}$.

Demikian pula dengan kelompok kedua, prilaku budaya yang berpaham liberalisme, hedonisme dan permisif saat ini merupakan fenomena umum di Kota Surakarta. Munculnya kelompok Punk di beberapa sudut Kota surakarta seperti di Pasar Kliwon tepatnya di Jl. Kapten Mulyadi perempatan Baturono, aktivitas mereka kebanyakan mengamen dan hidup secara berkelompok laki-laki dan perempuan membaur dengan pakaian ala punk dan pola hidupnya yang berpindah-pindah. Fenomena lain adalah budaya samenleven, hidup bersama tanpa ikatan perkawinan ${ }^{4}$.

Kelompok masyarakat ini kebanyakan hidup di bantaran sungai bengawan solo di wilayah perbatasan Kelurahan Semanggi dan Kabupaten Sukoharjo. Kurangnya kontrol sosial dan minimnya interaksi dengan tokoh agama dan tokoh masyarakat membuat kelompok sosial ini lebih exsis dan bahkan banyak dari mereka memiliki keturunan di luar nikah. Selain itu, fenomena kasus perceraian di kecamatan pasar Kliwon tertinggi ke tiga setelah Kecamatan Jebres dan Kecamatan Banjarsari. Dimana kasus talak ada 40 kasus, gugat cerai ada 180 kasus, yang

\footnotetext{
${ }^{3}$ suarajawatengah.id. Senin 10 Agustus 2020 / 05:05 Wib.

${ }^{4}$ Ibid.....hal....30
} 
kesemuanya total berjumlah 220 kasus $^{5}$. Salah satu faktor penyebab perceraian tertinggi di Kecamatan Pasarkliwon adalah kehadiran orang ketiga dalam keluarga atau perselingkuhan. Perselingkuhan menjadi faktor penyebab perceraian tertinggi di Kecamatan Pasar Kliwon yaitu sebanyak 46 kasus. Hal tersebut merupakan efek dari masuknya paham liberalisme dan budaya permisif di tengah masyarakat.

Kelompok lain, kelompok Islam garis keras telah teridentifikasi berada di wilayah Kelurahan Pasar Kliwon, Kelurahan Semanggi, Kelurahan Sangkrah, Kelurahan Mojo dan Kelurahan Joyosuran. Kelurahan-Kelurahan tersebut merupakan bagian dari 51 Kelurahan yang ada di Kota Surakarta dan masuk wilayah Kecamatan Pasar Kliwon. Berdasarkan hasil identifikasi kelompok binaan dan data yang ada di lapangan, Kecamatan Pasar Kliwon menjadi "lahan subur" berkembangnya paham keagamaan seperti salafi taklimy, salafi jihady, salafi haraky, jamaah tabligh (baca: Jaulah), kelompok minoritas syi'ah, MTA (Majlis Tafsir Al-Qur'an).

Paham Liberalisme, hedonisme, permisifisme pada dasarnya mempengaruhi pola dan model beragama di tengah umat Islam. Paham salafi sendiri dalam memahami teks-teks agama cenderung ke penafsiran makna harfiah, model penafsiran ini pada akhirnya akan menimbulkan sikap guluw berlebihan (ekstrim) dan jumud (staff) tektualis sehingga apa yang di pahami sesuai dengan apa yang ada pada teks tersebut tanpa ada syarah hadis dan tafsir yang di gunakan. Sehingga menimbulkan sikap takfir (pengkafiran), tasyrik (pemusyrikan), tabdi' (pembid'ahan), dan tasykik (sikap Ragu) ${ }^{6}$ yang terus saja muncul di tengah masyarakat.

Kelomppok Jama'ah tablig merupakan salah satu kelompok paham agama, yang di dalam metode dakwahnya berkeliling dari satu masjid ke masjid yang lain dari satu rumah ke rumah yang lain, hal ini bisa disebut "jawlah" atau "jamaah

\footnotetext{
${ }^{5}$ Badan Pusat Statistik Kota Surakarta (Pasar Kliwon Dalam Angka:2020)

${ }^{6}$ Syaikh idahram, Sejaharah Berdarah Sekte Salafi Wahabi, (Yogyakarta: Pustaka Pesantren 2013) hal.30
} 
khuruj". Pada pemahaman kelompok ini makna khuruj berarti khuruj fi sabilillah artinya keluar berjuang di jalan Allah mengorbankan jiwa dan raga, harta benda yang mereka miliki untuk kelangsungan dakwah mereka. Dasar pijakan dalil mereka adalah Qs Ali Imran ayat 110 pada kalimat "ukhrijat linnaasi” keluar berdakwah untuk manusia. Makna tafsir Syeikh maulana Ilyas "keluar" artinya keluar sebagai musafir yang mengadakan perjalanan. ${ }^{7}$ Kelompok ini berpusat di masjid An-nikmah terkenal dengan Masjid Tanjung Anom terletak di Kelurahan Joyotakan yang masuk dalam wilayah Kecamatan serengan, berbatasan langsung dengan Kecamatan Pasarkliwon.

Jaulah dalam aktifitas dakwahnya kebanyakan menyasar pada wilayah Pasar Kliwon khususnya di perbatasan antara Kecamatan serengan dan Kecamatan Pasar Kliwon tepatnya di bantaran sungai Jenes dan sungai bengawan Solo. Jaulah dalam dakwahnya terdiri dari satu atau tiga orang berputar mengunjungi dari rumah ke rumah kaum muslim yang ada di sekitar masjid tak jauh dari tempat muqim para jamaah tabligh berada. Khuruj bagi jamaah ini artinya keluar dan berpindah dari lingkungannya sehari-hari satu ke lingkungan yang lain yang baru dengan tujuan berdakwah. Adapun waktu khuruj ada yang 4 bulan selama seumur hidup, ada juga 40 hari dalam satu tahun, ada juga 3 hari dalam satu bulan sesuai situasi dan kondisi jamaah itu sendiri, tergantung pada bekal yang akan dibawa dan persiapan bekal untuk keluarganya yang akan di tinggal. ${ }^{8}$ Dalam hal bersosial jamaah ini cenderung dengan kelompoknya sendiri.

Kelompok mazhab Syi'ah di Surakarta, merupakan kelompok yang masih menjadi topik pembahasan dan permasalahan tersendiri bagi umat Islam karena keberadaannya yang bertaqiyyah, sehingga sulit untuk dikenali. Makna taqiyyah menurut ulama syiah sendiri merupakan upaya menutupi diri dengan merahasiakan

${ }^{7}$ H.As'ad Said Ali "Jamaah Tabligh. "http://www.nu.or.id/a,public-m,dinamic,-s.detailids.4-id.32537.lang..id-c.kolom-t.jamaah+tabligh-,phpx di akses tanggal 4 desember 2019

8 Tulisan ini pernah di presentasikan dalam $4^{\text {th }}$ Internasional Symposium of Journal Antropologi Indonesia July 12-15,2005 di UI Jakarta 
keyakinan syi'ahnya, berbaur dengan para penentangnya demi menjaga jiwa dan kehormatannya. Hal ini sulit bagi orang awam untuk membedakan antara syi'ah dan di luar syi'ah. ${ }^{9}$ Sedangkan kelompok Salafi (Jihady, Haraky, Taklimy) sebagian besar berkembang di Kelurahan Semanggi dan beberapa kelurahan seperti Kelurahan Sangkrah, Kelurahan Mojo dan Kelurahan Joyosuran. Masjid dan majlis taklim dijadikan pusat seluruh kegiatannya. ${ }^{10}$

Melihat fakta dan data keumatan yang sedemikian ini, Penyuluh Agama Islam Kota Surakarta merasa terpanggil untuk mengadakan kegiatan Bimluh (bimbingan penyuluhan dan pembangunan) dengan bahasa agama, ${ }^{11}$ Memberikan bimbingan dan penyuluhan melaui berbagai media dakwah terlebih dengan keadaan pandemik covid 19 saat ini memaksa penyuluh untuk berinovasi dalam mengembangkan metode dakwah, terlebih melalui media internet. Dalam hal ini peran aktif penyuluh sangat di harapkan untuk mengembangkan model dakwah yang berkonsep wasathiyah yang toleran dan moderat. Dengan model dakwah ini diharapkan para penyuluh agama khususnya mampu menjadi penengah sekaligus media dialog perdamaian diantara kelompok ekstrim di solo dan sekitarnya.

\section{B. Kondisi Sosial dan Keagamaan Masyarakat Pasarkliwon}

Kecamatan Pasarkliwon merupakan jantung perekonomian di kecamatan Pasar Kliwon dan sekitarnya, karena profesi masyarakat Kecamatan Pasarkliwon sebagian besar sebagai pengusaha batik, textil, pedagang baju muslim dan oleh-oleh haji, buruh bangunan, karyawan pabrik, transportasi, gojek, grab, PNS/TNI dan Pensiunan. Sebagian besar masyarakat bekerja sebagai buruh industri dan buruh bangunan. Banyak masyarakat yang berprofesi sebagai buruh industry (karyawan pabrik) tidak lepas dari posisi wilayah Kecamatan Pasarkliwon khususnya kelurahan

9 Syaikh Abdullah Bin Muhammad Menyingkap Hakekat Aqidah Syiah, (Jaringan Pembelaan Terhadap Sunnah.2015), hal.35

${ }^{10}$ Arif Yudi Asmara "Makalah dan Jurnal Penelitian .... Hal. 31

${ }^{11}$ Keputusan Menkowasbangpan Nomor:54/kep/MK/WASPAN/9/1999 tanggal 30 September 1999 tentang Jabatan Fungsional PA dan angka kreditnya. 
Pasarkliwon banyak terdapat sektor perindustrian. Namun jumlah pekerja buruh industri di pertengahan tahun 2020 ini prosentasenya menurun drastis seiring berkurangnya jumlah pengusaha dikarenakan kondisi resesi akibat merebaknya Covid 19.

Seacara geografis, luas wilayah Kecamatan Pasar Kliwon 4,82 km², yang terdiri dari 10 Kelurahan, 437 RW, 101 RT dan 27,695 KK. Kecamatan Pasarkliwon merupakan salah satu dari 6 Kecamatan yang berada dalam wilayah Kota Surakarta. Kecamatan Pasarkliwon berpenduduk 86.890 jiwa dengan laju pertumbuhan pertahun (2018-2019) 0,63\%, dengan kepadatan 18.026,97 km2. ${ }^{12}$ Secara sosial ekonomi masyarakat Pasarkliwon termasuk pada level ekonomi menengah kebawah. Akan tetapi, Kecamatan Pasarkliwon dikelilingi oleh perkampungan yhang rata-rata masyarakatnya memiliki pendidikan serta pekerjaan yang baik. Pendidikan Strata Satu (S1) dan bekerja sebagai pegawai negeri sipil (PNS) banyak dijumpai di kelurahan ini. Perkampungan tersebut diantaranya adalah kampung Semanggi Kelurahan Semanggi, kelurahan sangkrah dan Kelurahan Mojo.

Kampung Semanggi merupakan daerah yang termasuk wilayah Kelurahan Semanggi, memiliki 21 RT, 5 RW, 1.869 KK (Kepala Keluarga), dengan jumlah penduduk 6.103. Sebaran paham-paham keagamaan yang dapat kami identifikasi berbasis pada beberapa masjid di antaranya yang pertama Masjid Muhajirin terletak di Rt 06 RW 04 ada 40 KK Jama'ahnya berpaham Salafi Jihady,bergeser kearah selatan tepatnya di Kelurahan Mojo terdapat Masjid At-Taqwa yang terletak di Rt.02 Rw.07 ada 15 KK jamahnya berpaham salafy jihady, bergeser ke arah barat tepatnya di Kelurahan Joyosuran terdapat Masjid Muslimin terletak di kampung Kusumodilagan Rt.03 Rw.10 ada 30 KK yang jamaahnya berpaham salafy taklimy dan yang terakhir adalah Masjid Jami Al-Basyir terletak di Kelurahan Sangkrah Rt. 07 Rw.10 ada 35 KK jamahnya berpaham salafy jihady. Sedangkan sisa dari jumlah

${ }^{12}$ Badan Pusat Statistik Kota surakarta (Pasar Kilwon dalam angka....... 
masjid yang ada di empat kelurahan tersebut campuran dari berbagai mazhab sekitar 483 Kepala Keluarga (KK) bermazhab syafi'i dan Minoritas syi'ah.

\section{Metode Dakwah dalam Bimbingan dan Penyuluhan Wasatiyah Al-Islam}

Kemajuan dakwah Islam terus mengalami peningkatan dan berkembang pesat dari masa ke masa. Perkembangan tersebut tak lepas dari metode yang variatif dengan menitik beratkan pada metode yang akan diaplikasikan sesuai dengan kondisi umat saat ini. Terlebih dengan kondisi mewabahnya Covid 19 ini tentunya perlu innovasi dan kreasi dalam berdakwah. Agar pesan-pesan dakwah yang di embankan kepada seorang pembimbing maupun penyuluh agama Islam dapat di sampaikan dengan baik tanpa halangan dan di terima baik oleh jamaah binaan masjid maupun di luar masjid. Dengan dakwah efektif kreatif, didukung metode yang menarik dan berualitas sangat dibutuhkan terlebih di masa pandemi Covid 19 sekarang ini. Kunci dari keberhasilan dakwah ini adalah terletak pada metode. Halhal yang berhubungan dengan metode dakwah lebih diprioritaskan dari pada materi dakwah itu sendiri, Pepatah arab mengatakan: “At-Thoriqotu Ahammu Minal Maddah" (artinya: metode lebih penting daripada materi).

Ada beberapa metode dakwah yang dapat digunakan dalam pelaksanaan bimbingan dan penyuluhan baik di Majelis Taklim maupun di luar Majlis taklim di masjid binaan maupun di luar masjid binaan diantaranya:

1. Metode Ceramah.

Metode ini sangat revelan sejak awal penyebaran agama Islam di Nusantara ini metode dakwah dengan berceramah sudah dilakukan oleh para wali, ada yang berceramah di surau surau, masjid di tanah lapang, ada yang menggunakan dengan seni wayang, karena pada dasarnya tujuan dari metode ini hanya menyampaikan informasi atau pesan moral agama secara langsung antara pendakwah dan obyek dakwah. Metode dakwah dengan berceramah inilah yang paling mashur karena memiliki hubungan emosional positif antara pendakwah dan jamaah sebagai obyek dakwah, sehingga mampu mengarahkan dan mengajak para jamaah kepada kebaikan memperbaiki diri dengan menjaga prilaku anggota badan dari khilaf dan dosa. 
Rosulullah SAW sudah melakukan metode ini ketika beliau berdakwah di tengah masyarakat Madinah. ${ }^{13}$ Ada beberapa hal yang harus di lakukan jika ingin metode ini berjalan dengan baik, efektif dan efesien antara lain adalah: pertama, niat ikhlas hanya mencari ridha Allah SWT semata. Kedua, mempersiapkan materi ceramah dengan baik. Ketiga, fasahatul kalam bahasa yang jelas mudah di mengerti oleh jamaah bertutur baik dan santun. Keempat menjadikan subjek dakwah adalah teladan panutan bagi jamaah binaan sehingga akan melahirkan sikap emosional yang positif antara subjek dakwah dan objek dakwah.

2. Metode Diskusi dan Tanya Jawab

Untuk mengexplorasi sejauh mana pemahaman jamaah taklim dan binaan tentang materi yang sudah di sampaikan oleh seorang pembimbing dan penyuluh adalah dengan metode diskusi dan tanya jawab dari berbagai persolaan keagamaan baik pertanyaan yang muncul dari materi atau dari luar materi yang di sampaikan karena metode inilah yang akan mampu menyerap sekaligus mengidentifikasi problem dakwah pada obyek binaan, baik permasalahan figh muamalat, Syariah (hukum-hukum) dan hal-hal terkait dengan proses dakwah di lingkungan obyek dakwah. Sehingga berbagai permaslahan dapat diselesaikan dengan baik berdasarkan al-Qur'an dan hadits, ijma dan qiyas. Metode diskusi dan tanya jawab ini pada dasarnya akan membangun komunikasi dua arah antara subjek dakwah dan objek dakwah dengan memegang prinsip kekeluargaan, sehingga akan memudahkan transfer materi kepada objek dakwah (binaan).

\section{Metode Keteladanan (al-Uswah al-Hasanah)}

Untuk mencapai tujuan dakwah Islam dibutuhkan keteladanan (Uswatun alHasanah). Seperti apa yang telah dibahas tersebut di atas bahwa subjek dakwah adalah seyogyanya menjadi panutan atau teladan bagi objek dakwah /jamaah atau binaan di lingkungannya. karena pada dasarnya hakekat dan tujuan dakwah itu ialah

${ }^{13}$ Rif'at Mujahid Mutawaali, Manhaj ad-da'wah wa thuruq ad-du'aat (Kairo: Mathba, at al-azhar al-s yarif,1997) hal.65 
menggapai ridha Allah Swt mengajak manusia pada derajat yang lebih mulia untuk menata kemnbali pribadi, keluarga, masyarakat sesuai dengan bingkai norma agama yang telah tersurat dan tersirat dalam Al-Quran dan Al-hadis yang menjadikan Rosulullah Saw menjadi subjek dakwah sekaligus uswatun al-hasanah bagi umat Islam. Karena kehadiran Rosulullah Saw di tengah umat hanyalah untuk menyempurnakan akhlak bagi umat islam, membentuk pribadi yang utuh menggabungkan kehidupan material dan spiritual yang seimbang, jasmani dan rohani yang sehat sehingga mampu beribadah dengan baik dan sempurna, berinteraksi sosial dengan rasa kekeluargaan yang tinggi penuh tanggung jawab, menyebarkan rasa cinta kasih dan sayang kepada sesama manusia terlebih saudara semuslim. Hal itu tak lepas dari peran keteladanan Subjek dakwah di setiap lingkungannya, karena hal ini mejadi barometer keberhasilan dakwah bil hal penuh dengan keteladanan yang baik bermoral dan beradab sesuai norma agama.

Keteladanan yang baik merupakan satu metode mulia bila dibandingkan dengan metode dakwah lainnya, sebab metode ini sangat melekat pada sifat, sikap, akhlak subjek dakwah. Metode ini memiliki konsekwensi yang tinggi di sisi Allah Swt, karena tidak banyak orang yang mampu mensinergikan antara perkataan dan perbuatan. Allah SWT berfirman:

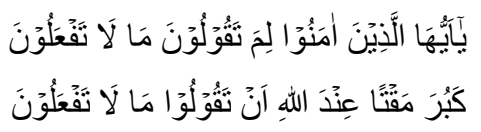

Artinya : "Hai orang-arang yang beriman, mengapa kamu mengatakan apa yang tidak kamu perbuat. Amat besar kebencian disisi Allah bahwa kamu mengatakan apa-apa yang tiada kamu kerjakan". (QS. Al-Shaf : 2-3)

Ayat tersebut di atas adalah bentuk pengingkaran Allah Swt kepada orangorang berucap sesuatu tapi tidak melaksanakannya. Ayat tersebut diatas menjadi motivasi sekaligus inspirasi bagi subjek dakwah dalam hal ini adalah pembimbing dan penyuluh agama Islam untuk senantiasa berhati-hati dalam berucap, bertindak, 
berprilaku, karena semua itu akan menjadi teladan yang baik bagi jamaah binaan dan lingkungannya. Seperti halnya Rasulullah SAW memberikan teladan bagi umatnya. Metode keteladanan ini cukup baik dan tepat untuk aktualisasikan di berbagai ranah dakwah terlebih di lingkungan merah artinya yang sama sekali belum tersentuh dakwah Islam.

\section{Metode dakwah melaui tulisan (bit-Tadwin)}

Di setiap (Pokjaluh) Kelompok Kerja Penyuluh berskala karisidenan yang meliputi beberapa kabupaten dan Kota memiliki majalah atau bulletin yang di terbitkan per 3 bulan sekali. Hal ini merupakan wadah kreatifitas penyuluh untuk menyalurkan aspirasi dakwahnya melalui tulisan yang akan di terbitkan dalam bentuk bulletin, dan akan di distribusikan lewat majlis taklim atau masjid setempat di setiap kota atau kabupaten. Untuk materi tentunya yang mengandung pesan dakwah.

\section{Metode dakwah melalui media Internet}

Dakwah pada hakekatnya adalah ajakan kepada manusia kearah yang lebih baik, secara individu maupun kelompok masyarakat agar ada kebaikan dan perubahan dalam memahami dan bermuamalat dengan baik sesuai aturan agama. Karena dakwah menjadi kebutuhan khususunya umat Islam. Kondisi Covid 19 tentunya menjadi tantangan tersendiri bagi pendakwah terutama penyuluh agama untuk berkreativitas dan berinovasi. Para penyuluh dapat menggunakan berbagai cara untuk menyampaikan pesan-pesan dakwahnya. Di era pandemi covid-19 ini transformasi dakwah menjadi acuan dalam melaksanakan strategi dakwah bagi para penyuluh Agama Islam. Karena transformasi ini bergerak terstruktur dari top down, dan bergerak dari bottom up secara kultural. Banyak hal yang berubah di era new normal saat ini, yang paling mencolok adalah perubahan aktivitas kegiatan dalam kehidupan masyarakat. yaitu berubahnya pola hidup khususnya dalam pola komunikasi yang selama ini dilakukan secara klasik saat ini lebih mengandalkan 
teknologi dengan berbagai layanan fitur media online, media sosial dalam bentuk zoom meeting, google meeting, baik yang digunakan dalam dunia kerja maupun dunia pendidikan yang semua itu berbasis virtual.

Adapun transformasi dakwah yang dapat dilakukan oleh para penyuluh dan juga pendakwah lainnya adalah melalui youtube, fasilitas website, mailing list, media online dan media sosial, google meeting, zoom meeting, berbasis virtual dengan mengajak diskusi melalui obrolan tentang keagamaan atau mengirim pesan keagamaan kepada seluruh anggota binaan majlis taklim, atau lebih luas lagi di luar jamaah majlis taklim yang dapat menjangkau dari berbagai kalangan dan masyarakat luas dengan menggunakan fasilitas chatting yang memungkinkan untuk berinteraksi secara langsung dengan menggunakan video call, google meeting, zoom meeting, sehingga strategi dakwah melalui tekhnologi di harapkan berjalan dengan baik dan masyarakat tidak merasa tertinggal dari berbagai informasi khususnya dakwah Islam.

\section{Impelementasi Dakwah Wasatiyah Al-Islam Melalui Bimbingan dan}

\section{Penyuluhan Kelompok}

\section{a. Memahamkan Makna Radikalisme Pada Kelompok Majlis Taklim Melalui Bimbingan dan Penyuluhan.}

Berdasarkan pada pemaparan dan beberapa kasus yang telah di terangkan di awal tulisan ini bahwa adanya sikap fanatik pada satu pemahaman tertentu atau salah satu aliran tertentu dalam Islam menyebabkan timbulnya dari sikap guluw (berlebihan) dalam beragama. Hal itu dilarang dalam Islam, terlebih di dalam manhaj Ahlu Sunnah wal Jamaah (ASWAJA). Manhaj ASWAJA ini merupakan manhaj yang paling dekat dan sesuai ajaran Rasulullah SAW para tabi'in, tabi'ut tabi'in dalam hal bermuamalah dan beragama.

Manhaj Ahlu Sunnah wal Jamaah memiliki sikap I'tidal; adil dalam bersikap, mempertimbangkan setiap gerak muamalahnya bersandar pada ajaran Rasulullah SAW. Sehingga tak heran jika manhaj ini sangat bertentangan dengan 
sikap ghuluw, terlebih di dalam bermuamalah sesuai dengan islam. Menurut arti bahasa, ghuluwun berarti melampaui batas atau berlebihan. ${ }^{14}$ Dalam kamus Bahasa Indonesia, Kata ghuluwun satu arti dengan ifrath, artinya berlebihan, sesuatu yang melampaui batas, ${ }^{15}$ melampaui batas dalam menghormati atau memuji seseorang, dan menempatkan kedudukannya pada tempat yang tidak sesuai.${ }^{16}$ tidak sepantasnya memuji dan memuliakan mahluk melewati batas ketetapan Allah Swt. Sikap guluw kadang tanpa disadari berawal dari hal-hal yang tidak penting dan remeh. Efek negatif sikap guluw ini juga sering diingatklan oleh Rasulullah Saw, Seperti halnya ketika Rosulullah Saw meminta kepada para sahabat dan ibnu abbas sepupu beliau untuk memungut kerikil kecil ketika selesai melontar jumroh aqobah pada hari kesepuluh Dzulhijjah. Beliau juga meminta agar lebih berhati-hati dengan sikap guluw.

Terkait dengan kerikil-kerikil kecil tersebut yang di terima oleh Rosulullah SAW. beliau memperingatkan untuk sederhana dalam memahami makna melempar jumroh karena pengertian yang mereka pahami dikhawatirkan akan keluar dari kontek yang sesungguhnya, sehingga bisa jadi melontar itu bermakna melempar setan, sebagaimana Nabi Ibrahim lakukan, maka bisa jadi akan muncul pemikiran bahwa melempar dengan batu yang kecil-kecil saja akan mendapatkan keutamaan terlebih dengan batu yang lebih besar pasti akan mendapatkan keutamaan yang jauh lebih besar. Hal seperti inilah yang diantisipasi oleh Roasulullah Saw sejak awal tentang sikap fanatic atau melampaui batas dalam praktek beragama di tengah kaum muslimin. ${ }^{17}$

Sikap fanatik atau melampaui batas inilah yang memicu sikap ekstrim dan fanatik dalam beragama di beberapa kelompok aliran keagaman di masyarakat.

\footnotetext{
${ }^{14}$ Ahmad Warson Munawwir, Al-Munawwir, (Surabaya: Pustaka Progressif, 19197), Cet. Ke XIV hal. 1015

${ }^{15}$ Atabik Ali dan Ahmad Zuhdi Muhdlar, Kampus Kontemporer Arab-Indonesia, (Yogyakarta: Yayasan Ali Makmur Pondok-Pesantren Krapyak, 1996,) hal.1357

${ }^{16}$ Mansur Said, Bahaya Syirik dalam Islam, (Jakarta: Pustaka Panjimas,1996) hal. 97

${ }^{17}$ Yusuf Al-Qaradhawi, al-sahwah al Islamiyah Bayna jumud wa al-Tatarruf, (Kairo: Daral-syuruq,2001) cet I hal.25
} 
Meski permaslahan ini sudah lama muncul di tengah masyarakat, namun jika melihat grafik dari kasus kekerasan atau intoleransi menunjukan angka kenaikan pada akhir dekade ini. Hal ini cukup meresahkan dan tidak bisa di anggap remeh lagi.

Sikap guluw bermetamorfosis pada sikap fanatisme yang akan melahirkan rasa paling benar sendiri, sikap inilah yang akan membawa pada kehancuran bagi pemilik sifat dan sikap ini. Ibnu Mas'ud mengatakan bahwa seorang sufi terkemuka yaitu Ibnu Athaillah mengingatkan, "Boleh jadi Allah membukakan pintu ketaatan kepada seseorang tetapi tidak dibukakan baginya pintu diterimanya sebuah amal, dan boleh jadi seseorang ditakdirkan berbuat maksiat tetapi itu menjadi sebab seseorang mencapai keridhaan Allah. Kemaksiatan yang melahirkan kehinaan atau perasaan bersalah lebih baik daripada ketaatan atau kebaikan yang melahirkan rasa bangga diri dan sombong"18.

Sikap paling benar sendiri sering terjadi pada kebanyakan kelompok aliran keagamaan saat ini, seperti halnya pengalaman seorang penyuluh agama Islam pada saat bimbingan dan penyuluhan melalui ceramah dilanjutkan dengan diskusi. Dalam diskusi ada salah satu jamaah menyampaikan bahwa hanya dengan sistem atau metode khuruj dan jawlah saja yang lebih baik sesuai dengan apa yang di anjurkan oleh Rasulullah dalam berdakwah, sementara sistem atau metode khutbah, ceramah dan mengajar bukanlah termasuk dakwah. Hal ini jauh berbeda dengan pendapat para ulama dan kebanyakan para aktivis dakwah bahwa sistem atau metode dakwah itu yang mudah di terima oleh masyarakat, mudah dipahami, mudah dikerjakan, mengandung kabar gembira, peringatan, teladan yang baik dalam kehidupan sehari hari. Rasululah bersabda : "Bassyiru wala Tunaffiru" artinya "berilah kabar gembira dan jangan beri kabar yang membuat orang lari dari dakwah tersebut".

Melihat kondisi dakwah dan permasalahan yang ada saat ini perlu perjuanagan hguna memberikan pemahaman Al-Qur'an dan Hadits yang baik dan sesuai tuntunan Rasulullah SAW, sekaligus memahamkan serta menanamkan paham

\footnotetext{
${ }^{18}$ Ibnu ajibah, Iqaz al-Hilmam syarh matn al-Hikam (Beirut: Dar al-Kutub al-Ilmiah)1998,
} hal.112 
moderasi Islam (wasathiyyah al-Islam. Berdasarkan analisis data dan fakta di lapangan maka dapat di simpulkan bahwa perlunya seorang penyuluh membentuk kelompok sasaran binaan majlis taklim, oleh sebab itu maka Penyuluh Agama Islam di wilayah Kecamatan Pasarkliwon telah membuat kelompok binaan, termasuk di dalamnya Kelurahan Semanggi bertempat di Masjid Muhajirin, Kelurahan Mojo di Masjid At-Taqwa, kelurahan Joyosuran di masjid Muslimin, dan yang terakhir kelurahan Sangkrah di masjid Jami’ Al-basyir.

Beberapa langkah dan uupaya dalam membentuk kelompok binaan majlis taklim untuk mendukung dakwah Wasatiyah al-Islam antara lain:

1) Silaturahmi dengan tokoh masyarakat diantaranya adalah ketua RT setempat, tokoh pada kelompok paham keagamaan, ketua takmir dan pengurus masjid setempat.

2) Memetakan kebutuhan dan minat kelompok sasaran melalui musyawarah dan rapat dalam rangka membentuk kelompok obyek binaan majlis taklim.

3) Memetakan tujuan dan sasaran binaan yang sesuai dalam rangka menetapkan program-program unggulan biinaan dan dari sinilah terbentuk majelis taklim di berbagai masjid setempat dengan klasifikasi pengajian bagi remaja, dan orang tua dengan rata-rata 40-50 jama'ah yang menghadiri kegiatan tersebut. Secara geograpis wilayah kelompok binaan ini masuk dalam kategori binaan perkotaan yang memiliki ciri dan corak pemikiran yang berbeda dengan kelompok binaan di pedesaan atau wilayah terpencil.

Dalam memahami agama kelompok binaan perkotaan cenderung realistis, rasionlis, individualistis dan liberalis. Namun ada sebagian yang cenderung lebih keras dalam memahami teks-teks keagamaan tanpa melihat pertimbangan sumber hukum yang lain. Melihat fenomena dan geografis obyek dakwah maka ada beberapa langkah metode bimbingan dan penyuluhan diantaranya adalah melalui diskusi dan argumen. Metode ini sangat relevan dan dapat di terima oleh sebagian besar kelompok-kelopmpok Islam yang ada di perkotaan, karena dengan metode ini kelompok binaan menjadi wadah pembelajaran bersama saling bertukar ilmu agama 
dari berbagai mazhab, mereka saling menerima, memahami dan bahkan menyadari bahwa ilmu agama itu sangatlah luas. Metode diskusi dan argumen ini sangat efektif serta dapat di terima oleh berbagai kelompok keagaman yang ada terlebih obyek dakwah dan kelompok binaan.

Bimbingan dan penyuluhan pada obyek dakwah di beberapa masjid di 4 kelurahan tersebut yaitu Masjid Muhajirin di Kelurahan Semanggi, Masjid AtTaqwa di Kelurahan Mojo, Masjid Muslimin di Kelurahan Joyosuran dan Masjid Jami' Al-basyir di kelurahan Sangkrah, memiliki misi dan tujuan untuk memahamkan ajaran Wasahatiyah Al-Islam secara detail dan transparan serta memaparkan khazanah sejarah pemikiran antar mazhab agar dapat membuka wawasan pemikiran kelompok binaaan binaan pada khususnya dan kelompok masyarakat pada umumnya bahwa Islam adalah agama universal, toleran dengan perbedaan yang ada, karena Islam akan terus berkembang menembus batas waktu, peradaban dan perbedaan, membuka cakrawala ilmu yang bermanfaat bagi umat manusia.

\section{b. Bimbingan dan Penyuluhan Tentang Paham Liberal Dalam Beragama}

Paham liberalisme sejatinya muncul dari ketidakpuasan satu kelompok dalam beragama, mereka tidak merasa puas dengan wahyu yang diturunkan Allah SWT berupa nash-nash alquran yang mengandung hukum syar'i dan hadis Nabi dengan dalih sudah tidak sesuai dengan era saat ini. Sehingga sifat cuek dan mempermudah urusan agama, cenderung mengikuti budaya lain yang tak sesuai dengan norma ketimuran dan nilai-nilai Islam, selalu saja menghiasi prilaku mereka. Mereka memiliki pemikiran yang berbeda dengan kebanyakan kelompok muslim lainnya. Seperti halnya mereka berfikiran bahwa minuman keras (khamar), memang haram di timur tengah karena kondisi cuaca di sana sangat panas tidak cocok iklimnya bagi alkoholik jika dipaksakan untuk minum-minuman keras akan membahayakan bagi peminumnya, beda dengan iklim dingin dan tropis dapat di halalkan karena tidak membahayakan bahkan bermanfaat menghangatkan tubuh di 
saat udara dingin. kebanyakan mereka juga menganggap Al-quran adalah produk budaya (Mumtaz tsaqofi) karena diturunkan di Arab, dan lain-lain.

Kajian dan pembahasan tentang paham liberalisme sudah terlalu sering di bahas di forum-forum baik nasional maupun internasional dan dan sebagian sudah mengakar rumput di kalangan akademisi formil, kelompok kelompok kajian muda Islam yang tumbuh subur di lingkungan kampus dan sebagian kelompok cendekia sayap organisasi keagamaan. Namun pemikiran ini menembus batas mempengaruhi setiap individu semua orang di karenakan arus globalisasi dan perkembangan teknologi informasi yang sangat cepat sekali dan tak terkendali.

Leonard Binder dan Charles Kurzman dua pemikir (menyimpulkan makna "Islam Liberal" yang justru gagasannya memicu polemik di Indonesia) pada hakekatnya memiliki pengertian yang berbeda. Seperti halnya Charles Kurzman menilai bahwa Leonard Binder berpendapat "Islam bagian dari liberalisme" ( $a$ subset of Islam) untuk kepentingan modernitas, Charles Kurzman justru berusaha menghadirkan kembali masa lalu sebagai counter terhadap Islam postradisionalis artinya tidak terjebak pada ortodoksi, melepaskan dari pengaruh dan ketergantungan pada teks keagamaan dan sekulerisasi. Perbedaannya terletak kepada pandangan terhadap lokalitas, karena Islam Liberal menjadikan modernitas sebagai rahmat bagi umat manusia yang patut disyukuri." 19

Fase modernitas tak dapat di pungkiri oleh dunia Islam dengan segala efeknya positif maupun negatifnya, merupakan tantangan yang harus di hadapi dunia Islam khususnya umat Islam yang di tuntut untuk tidak berfikiran sempit dan jumud (Stagnan) dalam melihat perkembangan modernitas. Umat Islam harus berupaya menyelesaikan berbagai permasalahan di tengah umat seperti halnya produk hukum, tajdid (Upaya pembaharuan Hukum), fikih kontemporer, kerukunan hidup antar umat beragama, sesama pemeluk agama, pemeluk agama dan pemerintah, dan salah satunya adalah moderasi beragama atau Wasathiyah., merupakan salah satu upaya

\footnotetext{
${ }^{19}$ Rumadi. Masyarakat Post-Teologi, (Bekasi: Gugus Press, 2002), 116-118.
} 
untuk menjaga berbagai hal tentang isu-isu krusial di berbagai lini permasalahan keagamaan yang bertujuan untuk menjaga kualitas hidup beragama dan keberagamaan masyarakat, melestarikan ajaran Islam yang kesemuanya itu dapat di maksimalkan oleh masyarakat pada umumnya dan khususnya umat Islam.

Liberalisme merupakan istilah asing yang sering di tujukan pada Islam sehingga kebanyakan masyarakat menyebutnya dengan Islam liberal. Kalimat Islam liberal memiliki konotasi kebebasan beragama, paham ini tidak mewakili umat Islam secara menyeluruh, namun hanya sebagian kecil dari kelompok umat Islam. Liberalisme bermakna cara pandang dalam memahami arti kebebasan, kebebasan tak terbatas, ambigu hingga ragu dalam memahami agama, dan cenderung longgar dalam beragama. Hal ini sesuai dengan pendapat Syamsuddin Arif tentang cakupan paham Liberalisme yang meliputi tiga hal :

1) Kebebasan berfikir tanpa batas alias free thinking

2) Senantiasa meragukan dan menolak kebenaran alias sophisme

3) Sikap longgar dan semena-mena dalam beragama (loose adherence to and free exercise of religion)..$^{20}$

Pada akhirnya kebebasan berfikir inilah yang merubah cara berfikir mereka bahwa negara tidak boleh mencampuri urusan spiritual warganya karena hal itu merupakan urusan pribadi dan negara tidak boleh mencampurinya. Konsekwensi cara berfikir ini berimbas pada cara mengekspresikan makna liberlisme itu sendiri, bebas dan longgar dalam memahami cara beragama mereka, bebas bergaul tanpa memandang laki-laki dan perempuan, bebas berpakaian tanpa mengenal batas aurat, menganggap akal lebih tinggi dari wayhu sehingga cara memahami teks-teks agama sesuai akal fikir mereka, menikah beda agama, dengan cara apa saja tanpa melihat norma-norma agama.

\footnotetext{
${ }^{20}$ Syamsuddin Arif, Orientalis dan Diabolisme Pemikiran, Jakarta: Gema Insani Press (GIP), Februari 2008, 79.
} 
Prilaku dan Kecenderungan kebebasan ini tampak nyata adanya di Kelurahan Semanggi khususnya di bantaran Sungai Bengawan Solo. Tradisi lain yang tak kalah menarik adalah budaya "mitoni" yang sudah berkolaborasi dengan budaya luhur suku jawa dan nilai agama yang cukup lama, masih saja dibenturkan hanya karena adanya perubahan mindset cara berfikir masyarakat yang mampu merubah tata cara prosesi "mitoni", yakni prosesi mitoni yang di barengi dengan kebiasaan minuman keras, berjudi dengan kartu yang rata-rata dilakukan oleh muda mudi. Hal inilah yang akan mengakibatkan pergeseran nilai-nilai budaya dan agama karena tidak mencerminkan kedua nilai tersebut terlebih nilai luhur bangsa ini.

Atas dasar uraian tersebut di atas, maka pemberian materi tentang paham washatiyah pada bimbingan dan penyuluhan perlu dititikberatkan pada upaya-upaya yaitu:

1) Untuk memberikan dan menguatkan dasar pemahaman Islam antara lain terdiri dari aqidah, syariat dan akhlak satu sama lainnya saling menguatkan dan tidak dapat dipisahkan.

2) Menjadikan Islam sebagai agama "Rahmatan lil alamiin" yang bersifat genuine bersumber pada teks-teks klasik dalam bentuk rumusan produk hukum dan menganggap modernitas adalah sebuah anugrah yang harus di syukuri. Menggabungkan antara aspek modernitas dan tradisi adalah sebuah keniscayaan artinya bahwa rumusan produk hukum yang bersifat genuine dan klasik yang tertuang dalam berbagai kitab dapat diterapkan sebagai problem solving keumatan yang bermetamorfosis menjadi fiqh sosial kontemporer. Pengembangan fiqh sosial kontemporer tidak serta merta akan mereduksi peran khazanah klasik. Maka, dengan dasar keyakinan ini, kreatifitas dalam pengembangan fiqh sosial diharapkan tidak tercerabut dari akar tradisi ortodok. Untuk menyikapi khazanah klasik tersebut, digunakanlah prinsip "almuhafadhotu 'ala qodimis sholih wal akhdzu bil jadidil ashlah" yang artinya 
mempertahankan nilai-nilai lama yang baik dan bersikap terbuka terhadap nilainilai baru yang terbukti lebih baik. ${ }^{21}$

3) Mengedepankan silaturrahmi dan diskusi. Diskusi dan silaturrahmi yang tulus, saling terbuka dan saling menerima kritik membangun, harus dimiliki dan dilakukan agar supaya tidak ada prasangka antar kelompok. Kegiatan silaturrahmi ini dapat di lakukan dalam bentuk kegiatan sarasehan, pentas seni dan budaya Islam, seni musik dan juga olahraga, agar tidak terkesan formal. Sehingga sikap ekstrimitas dan pemikiran liberal dapat di cegah.

\section{c. Bimbingan dan Penyuluhan Agama Tentang Pemahaman Konsep Wasathiyyah}

Bimbingan dan penyuluhan tentang wasathiyyah al-Islam atau moderasi Islam pada kelompok binaan dan jamaah memiliki tantangan tersendiri karena mindset keyakinan dan pemahaman keagamaan mereka sudah menyatu dengan salah satu mazhab mashuuroh terkenal di kalangan umat Islam Indonesia. Selain sudah mengakar lama di tengah umat Islam, hal ini merupakan sebuah tantangan yang kami anggap sudah biasa terjadi di lapangan dakwah, prinsip kami para penyuluh tak pernah berhenti untuk menyampaikan dakwah terlebih pemahaman yang benar tentang ajaran Agama Islam yang penuh damai dan cinta kasih rahmat bagi sekalian alam. Sebagaimana Rasulullah contohkan dalam Firman Allah SWT QS. Al-Anbiya' 107:

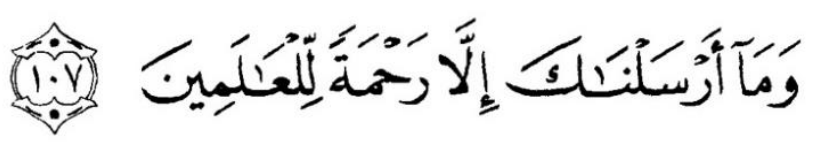

artinya : "Dan tiadalah kami mengutus kamu, melainkan untuk menjadi rahmat bagi semesta alam". ${ }^{22}$

${ }^{21}$ http://imron-rosidi.blogspot.co.id diakses tanggal 14 Januari 2017 pukul 22.01

${ }^{22}$ QS Al-Anbiya ayat 107 
Kata Rahmatan merupakan masdar ghoiru mim berakar dari kata al-rahman, yaitu kasih sayang Allah yang tentu mencakup seluruh ciptaan-Nya. Oleh karena itu, Islam tidak bisa membatasi rahmat-Nya, hanya untuk umat Islam, karena ciptaan Allah melampaui sekat keagamaan, organisasi, negara, dan bahkan batasan manusia. ${ }^{23}$ Artinya, dengan memahami agama ini dengan baik dan benar sesuai koridor yang sudah digariskan al-Qur'an dan Hadits maka rahmat bagi alam semesta ini akan terwujud, salah satunya adalah menjadikan moderasi agama sebagai rujukan dalam keberagamaan yang santun damai, toleransi dan mengedepankan kasih sayang di antara sesama anak bangsa dan pemeluk agama. Paham ini juga di kenal dengan konsep wasathiyyah.

Al-Qur'an telah disepakati oleh para Ulama Islam yang tergabung dalam consensus (Ijma') ulama bahkan setiap generasi dari masa Rasulullah SAW sampai hari kiamat, bahwa Al-Qur'an adalah referensi berbagai hal baik itu aqidah, syariat, muamalat, konsep washatiyah maupun yang besrsifat ilmiah dan menjadikannya rujukan utama dan tertinggi dalam Islam. Hakekat arah pemikiran Washatiyah telah di jelaskan oleh Al-Qur'an secara mendasar, relevan, dan akuratif di tengah masyarakat muslim. Al-qur'an banak menjelaskan di banyak ayat dalam Al-Qur'an. Baik yang tersirat maupun tersurat sehingga dari Al-qur'an ini muncullah konsepkonsep atau paham manhaj moderasi Islam di setiap lini prikehidupan umat khususnya umat muslim.

Lebih jauh untuk mengetahui bagaimana Al-Qur'an bicara tentang alwashatiyah, Muhammad Ali As-Shalabiy (2007M) dalam karyanya "AlWashathiyah dalam Al-Qur'an "menuliskan berbagai hal tentang wasathiyah dia berpendapat bahwa akar kata Washathiyah dalam Al-Qur'an ada 4 (empat) kata yang di sebut dengan arti yang hampir sama maknanya ${ }^{24}$

\footnotetext{
${ }^{23}$ Dr. Nawiruddin, M.Ag. dan Andang B.Malla, M.Ag 'Pembinaan Umat Berbasisi Multikultural (Jakarta: Pustaka Rabbani Indonesia,2014),hal.66-67

${ }^{24}$ Ali Muhammad As-Shalabiy, Al-Wasathiyah fil Qur'an Al-Karim, hal 16-25
} 
1) Washatiyah bermakna sikap Adil dan pilihan.

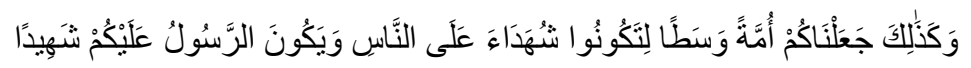

Artinya: "Dan demikian (pula) Kami telah menjadikan kamu (umat Islam), umat yang adil dan pilihan agar kamu menjadi saksi atas (perbuatan) manusia dan agar Rasul (Muhammad) menjadi saksi atas (perbuatan) kamu". (QS. Al-Baqarah: 143)

Di riwayatkan oleh Abu Said Al-Khudri ra, bahwa dalam ayat ini Nabi SAW menjelaskan kalimat ummatan wasathan bermakna "keadilan". At-thabari ahli tafsir memberikan makna "wasathan" yang berarti "posisi paling baik dan paling tinggi". ${ }^{25}$ At-Thabari mengutip Ibnu Abbas ra, Mujahid dan Atha' saat menafsirkan ayat 143 berkata: "Ummatan Washathan adalah "keadilan" sehingga makna ayat ini adalah "Allah menjadikan umat Islam sebagai umat yang paling adil". ${ }^{26}$ Dan "wasathan adalah keadilan, karena sesuatu yang paling baik adalah yang paling adil" kata Al-Qurthubi ${ }^{27}$. Syekh Ibnu Katsir memberikan makna wasathan pada ayat ini artinya paling baik dan paling berkualitas". ${ }^{28}$ Abdurrahman As-Sa'diy dan para ahli tafsir lainnnya seperti Rasyid Ridha menafsirkan makna washathan pada ayat ini berarti keadilan dan kebaikan" ${ }^{29}$.

${ }^{25}$ Ibnu Jarir At-Thabari, Tafsir At-Thabari, vol 2 (Kairo: Maktabah At-Taufiqiyah, 2004), hal 7 ,

${ }^{26}$ Ibid, hal 8

${ }^{27}$ Muhammad bin Ahmad Al-Anshari Al-Quthubi, Al-Jami' Li Ahkam Al-Quran (Tafsir Al-Qurthubi), vol 1, (Kairo: Maktabah Al-Iman, tt), hal 477

${ }^{28}$ Ibnu Katsir, Tafsir Al-Quran Al-adzim, vol 1, (Beirut: Daar Al-Fikri, 1994), hal 237

${ }^{29}$ Ali Muhammad As-Shalabiy, Al-Wasathiyah fil Qur'an Al-Karim, hal 17 
2) Washatiyah bermakna pertengahan dan paling baik.

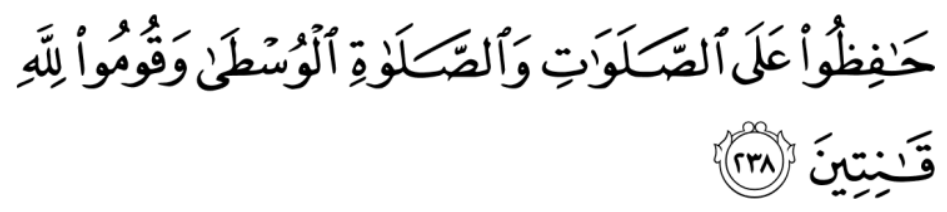

Artinya: "Peliharalah semua shalat(mu), dan (peliharalah) shalat wusthaa.

Berdirilah untuk Allah (dalam shalatmu) dengan khusyu'” (QS. Al-Baqarah: 238).

At-Thabari menjelaskan bahwa maksudnya washathan pada ayat tersebut diatas adalah shalat ashar, dimana posisi shalat ashar terletak di tengah-tengah diantara shalat lainnya yaitu subuh dan zuhur serta maghrib dan isya". ${ }^{30}$ ALQurthubi berkata: "Al-Wustha bentuk feminism dari kata wasath yang berarti terbaik dan paling adil". ${ }^{31}$ Ibnul Jauziy, menjelaskan ada 3 makna yang tersirat pada ayat ini: pertama, tentang posisi shalat di pertengahan. Kedua, paling tengah ukurannya dan ketiga: karena paling afdhal kedudukannya". ${ }^{32}$ Maka kata makna yang tepat pada kata wustha dalam ayat ini adalah "paling tengah, paling adil, dan paling baik" tidak ada kata makna lain dari kata wustha dalam ayat ini.

3) Wasathiyah bermakna paling baik, ideal, paling adil dan berilmu.

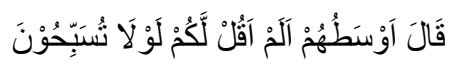

Artinya: "Berkatalah seorang yang paling baik pikirannya di antara mereka: "Bukankah aku telah mengatakan kepadamu, hendaklah kamu bertasbih (kepada Tuhanmu)?" (QS. Al-Qalam: 28)

\footnotetext{
${ }^{30}$ Ibnu Jarir At-Thabari, Tafsir At-Thabari, vol 2, hal 567

${ }^{31}$ Al-Quthubi, Al-Jami' Li Ahkam Al-Quran (Tafsir Al-Qurthubi), vol 1, hal 296

32 Al-Quthubi, Al-Jami' Li Ahkam Al-Quran (Tafsir Al-Qurthubi), vol 1, hal 296
} 
Dalam tafsir At-Thabari Ibnu Abbas ra dan At-Thabari berkata: Yang di maksud dengan kata aushatuhum adalah "Orang yang paling adil dari mereka". ${ }^{33}$ Pada ayat 28 surat Al-Qalam ini Al-Qurthubi menafsirkan yang dimaksudkan adalah "orang yang paling Ideal, paling adil dan paling berakal dan paling berilmu". ${ }^{34}$ Dalam ayat ini juga dapat disimpulkan bahwa makna kata ausathuhum adalah "paling baik, paling adil atau ideal dan paling berilmu".

4) Wasathiyah bermakna di tengah-tengah atau pertengahan

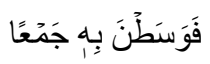

Artinya: "Dan kuda-kuda perang menyerbu ke tengah-tengah kumpulan musuh" (QS.Al- Adiyat: 5).

Kebanyakan ahli tafsir di antaranya At-Thabari, Al-Qurthubi dan Al-Qasimi menjelaskan ayat tersebut di atas dengan makna "berada ditengah-tengah musuh" ${ }^{35}$ Demikianlah hakikat washathiyah dalam Al-Qur'an sesuai dengan penafsiran yang dipercaya dan otoritatif berdasarkan riwayat yang shahih.

Dari empat ayat Al-Qur'an yang berbeda-beda tentang kata wasathiyah di atas, dapat disimpulkan secara pasti bahwa wasathiyah dalam kalimat dan istilah AlQur'an adalah keadaan paling adil, paling baik, paling pertengahan dan paling berilmu.Sehingga umat Islam adalah umat yang paling adil, paling baik, paling unggul, paling tinggi dan paling moderat dari umat yang lainnya.

\section{d. Dakwah dan Praktik amaliyah Keagamaan Islam Washatiyah}

\footnotetext{
${ }^{33}$ Ibnu Jarir At-Thabari, Tafsir At-Thabari, vol 16, hal 110

${ }^{34}$ Al-Quthubi, Al-Jami' Li Ahkam Al-Quran (Tafsir Al-Qurthubi), vol 10, hal 126

${ }^{35}$ Ali Muhammad As-Shalabiy, Al-Wasathiyah fil Qur'an Al-Karim, hal 25
} 
Implementasi konsep Islam sebagai Rahmatan lil alamin maka amaliyah keagamaan Islam wasathiyah ini perlu di sebarkan dan didakwahkan. Karena dakwah merupakan jalan kenabian dan kerasulan yang diteruskan dan wariskan kepada umat Islam sebagai bentuk tanggungjawab kelangsungan umat dan rasa cinta terhadap agama Islam. Dengan jalan dakwahlah, Islam dapat berkembang dengan baik dan pesat, tatanan kehidupan masarakat muslim semakin baik dan tertata. Karena tujuan dan fungsi dakwah adalah (tauhidul ummah) mempersatukan ummat, (tansiqul ummah) mensinkronkan gerakan dakwah, (taswiyatul manhaj) menyamakan persepsi pola keagamaan Ahlussunnah wal Jama 'ah, (I'tho'i uluwiyah lilwahyi minal aqli) mendahulukan wahyu dari akal dan (himayatul ummah) melindungi ummat dari akidah dan pemikiran sesat, muamalat yang haram, dan konsumsi yang haram, termasuk membentengi ummat Islam menghadapi rongrongan dari luar seperti upaya pemurtadan, dan sebagainya.

Adapun sifat dan ciri praktek amaliyah keagamaan washathiyah sejatinya terletak pada niali-nilai washatiyah itu sendiri antara lain sebagai berikut: ${ }^{36}$

1) Mampu memahami dan menghayati nilai keseimbangan (tawazun) dengan berkembangnya potensi yang ada pada manusia baik fisik, jiwa dan rohani harus sama-sama berkembang menuju pada keselarasan dan keseimbangan yang beradab.

2) Memahami dan menyadari bahwa hakekat manusia sebagai makhluk individual dituntut mampu menghargai kehidupan lain, orang lain, kelompok lain, dengan prinsip saling menghormati dan saling.membutuhkan.

3) Menghormati dan bersedia menerima perbedaan dalam keragaman dari berbagai hal baik keragaman fisik, warna kulit, suku bangsa, keyakinan, pemikiran, pandangan dan sebagainya.

\footnotetext{
${ }^{36}$ Afrizal Nur, Mukhlis Lubis, "Konsep Wasathiyah Dalam Al-Quran; (Studi Komparatif Antara Tafsir Al-Tahrîr Wa At-Tanwîr Dan Aisar At-Tafâsîr)", Jurnal: An-Nur Vol.4 No. 2, 2015), 207.
} 
4) Mampu menguasai managemen konflik dalam memecahkan berbagai hal permasalahan sosial keagamaan dengan mengedepankan dialog, komunikasi dan terbuka dengan berbagai kalangan dan kelompok yang memliki perbedaan agama, budaya dan peradaban.

5) Mampu menghindari prilaku kehidupan hedonisme, materialisme yang akan menjauhkan dari kehidupan spiritualisme, lebih mengutamakan kehidupan jasmani dengan mengabaikan kehidupan rohani.

6) Mampu bersikap adil sebagai penengah tidak condong ekstrim kanan dan kiri, tidak merasa paling benar, tetapi bersikap menengah, dan adil.

Impelementasi dakwah sesuai pemahaman konsep wasathiyyah al-Islam tersebut di atas dampaknya terlihat pada moderasi Islam masyarakat Kecamatan Pasarkliwon dalam beragama semakin baik dan terarah. Selain itu, wawasan amaliyah keagamaan wasathiyah Islam sebagian sudah mewarnai kehidupan keagamaan meski beberapa kelompok belum bisa menerima konsep ini. Kecamatan Pasarkliwon merupakan kelompok binaan perkotaan yang 60\% berbasis kelompok inteletual, tidak ada hal yang sulit untuk mengaplikasikan konsep wasathiyah Islam meski kelompok keagamaan dan kaum liberal diminati oleh pemuda dan kaum remaja. Mereka tetap mampu memahami dan mengaktualisasikan ajaran konsep wasathiyyah al-Islam seperti yang diajarkan oleh oleh Rasulullah SAW, agar terbentuk keberagamaan y ang toleran, terbuka dan berpedoman secara penuh dengan ajaran agama Islam yang sempurna.

\section{E. Kesimpulan}

Melalui Al-Qur'an dengan beberapa teks keagamaan, Islam telah mengajarkan kita dan umumnya umat Islam yang di harapkan mampu menegakkan kebenaran dan mencegah kebatilan. Salah satu kebaikannya adalah mampu mengahadirkan konsep moderasi beragama yang bertransformasi sebagai (wasathiyah al-Islam) yang menjadikan nilai kedilan, keberimbangan dan nilai kebaikan jauh lebih utama khususnya kepada umat Islam, dan pada umumnya diluar 
Islam. Meski dalam proses mewujudkan Konsep wasathiyah al- Islam ini menghadapi tantangan yang tidak ringan di medan dakwah, namun sekali lagi bagi penyuluh hal itu dianggap ringan jika memang hal itu disertai rasa ikhlas karena Allah Swt.

Pada tataran individu maupun kelompok konsep wasathiyyah al-Islam dalam kehidupan sehari-hari akan berjalan dengan baik jika diawali dan didasari dengan sikap (positive thinking) berfikiran positif terhadap kelompok lainnya, hingga akan terbangun sikap dinamis, kooperatif, dan terbuka dengan kelompok lainnya. Sehingga dakwah wasathiyah melalui bimbingan dan penyuluhan ini akan tampak baik dan menghasil hal yang baik pula. Oleh karena itu, maka dalam proses dakwah perlu adanya persiapan yang matang, terarah, terukur, terevaluasi dengan baik, sehingga akan dapat diketahui kualitas dan kuantitas serta hasil dari bimbingan dan penyuluhan, khususnya bimbingan dan penyuluhan dalam rangka memberi pemahaman dan penanaman konsep wasathiyah pada jamaah binaan di empat masjid yang berada di Kecamatan Pasarkliwon. Sehingga pada akhirnya dapat mendatangkan kedamaian dalam koridor moderasi beragama, toleran terhadap perbedaan yang ada, mengutamakan (positive thinking) berfifkir positif terhadap semua kelompok agama, golongan maupun individu, sehingga dapat menghadirkan Islam sebagai Rahmatan lil alamiin.

Penyelenggaraan dakwah (Bimluh) bimbingan dan penyuluhan di Masjid Muhajirin di Kelurahan Semanggi, Majlis taklim di Masjid At-Taqwa Kelurahan Mojo, Majlis Taklim Masjid Muslimin di Kelurahan Joyosuran, Majlis Taklim di Masjid Jami” Al-Basyir Kelurahan Sangkrah, merupakan bentuk usaha dan ikhtiar penyuluh agama Kecamatan Pasarkliwon untuk menumbuhkan dan menanamkan konsep paham wasathiyyah al-Islam sehingga nilai (keadilan), at-tawazun (keseimbangan) dan nilai tasamuh (toleran), dapat di terima secara bertahap mempengaruhi mindset cara berfikir masing-masing kelompok binaan, terutama dalam beragama dan cara mensikapi perbedaan yang ada diantara kelompok agama maupun individu. Ada beberapa indikasi positif yang dapat dilihat dari blanko 
pemantauan dan dari hasil wawancara langsung serta hasil diskusi dengan jamaah (binaan) bahwa masing masing jamaah (binaan) sudah bisa saling menghargai perbedaan dan tidak menonjolkan perbedaan, terbuka dengan jamah yang datang dari luar masjid, bersedia dialog dengan siapapun terlebih dengan aparat pemerintah.

\section{Daftar Pustaka}

Abd. Malik Usman, Islam Rahmah dan Wasathiyah: Paradigma Keberislaman Inklusif, Toleran dan Damai, Jurnal Humanika Vol. 15, No, 1 (September 2015)

Afrizal Nur, Mukhlis Lubis, "Konsep Wasathiyah Dalam Al-Quran; (Studi Komparatif Antara Tafsir Al-Tahrîr Wa At-Tanwîr Dan Aisar At-Tafâsîr)", Jurnal: An-Nur Vol.4 No. 2, 2015), 207.

Arif Yudi Asmara.S.Ag., M.SI "Makalah dan Jurnal Penelitian" (solo: Mimbar Pokjaluh 2009)

Ahmad Warson Munawwir, Al-Munawwir, (Surabaya: Pustaka Progressif, 19197), Cet. Ke XIV.

Atabik Ali dan Ahmad Zuhdi Muhdlar, Kampus Kontemporer Arab-Indonesia, (Yogyakarta: Yayasan Ali Makmur Pondok-Pesantren Krapyak, 1996,)

Ali Muhammad As-Shalabiy, Al-Wasathiyah fil Qur'an Al-Karim.

Al-Quthubi, Al-Jami' Li Ahkam Al-Quran (Tafsir Al-Qurthubi), vol 10,

Ali Muhammad As-Shalabiy, Al-Wasathiyah fil Qur'an Al-Karim,

Al-Quthubi, Al-Jami' Li Ahkam Al-Quran (Tafsir Al-Qurthubi), vol 1,

Ali Muhammad As-Shalabiy, Al-Wasathiyah fil Qur'an Al-Karim,

Badan Pusat Statistik Kota Surakarta (Pasar Kliwon Dalam Angka:2020)

Dr. Nawiruddin, M.Ag.dan Andang B. Malla, M.Ag. 'Pembinaan Umat Berbasisi

Multikultural (Jakarta: Pustaka Rabbani Indonesia,2014)

Departemen Agama RI, Al-Qur'an dan Terjemahan: Transliterasi Arab-Latin Model Kanan Kiri (Semarang: Asy-Syifa', 2000)

Data Kantor Urusan Agama Kecamatan Pasar Kliwon Tahun 2020

Data Keagamaan Kementerian Agama Kota Surakarta tahun 2020

H.As'ad Said Ali "Jamaah Tabligh." http://www.nu.or.id/a,public-m,dinamic,s.detail-ids.4-id.32537.lang..id-c.kolom-t.jamaah+tabligh-,phpx di akses tanggal 4 desember $2019 \mathrm{http}: / /$ imron-rosidi.blogspot.co.id diakses tanggal 18Juli 2019 pukul 18.32

Imam Ibnu atsir "An-Nihayah fi Gharibil atsar" Tahqiq Syaikh Khalil Ma'mun Syiiha (Beirut: Darul Ma'rifah)1979.

Ibnu Jarir At-Thabari, Tafsir At-Thabari, vol 2 (Kairo: Maktabah At-Taufiqiyah 2004)

Ibnu Katsir, Tafsir Al-Quran Al-adzim, vol 1, (Beirut: Daar Al-Fikri, 1994), 
Ibnu Jarir At-Thabari, Tafsir At-Thabari, vol 2,

Ibnu Jarir At-Thabari, Tafsir At-Thabari, vol 16,

Ibnu ajibah Iqaz al- Hilmam syarh matn al-Hikam (Beirut: Darul al-Kutub alIlmiah) 1998, hal.112

Keputusan Menkowasbangpan Nomor:54/kep/MK/WASPAN/9/1999 tanggal 30 September 1999 tentang Jabatan Fungsional PA dan angka kreditnya.

Martin Van Bruinessen, "Genealogies of Islamic Radicalism in post-Suharto Indonesia", Southeast Asia Research no 2, 2002.

Mansur Said, Bahaya Syirik dalam Islam, (Jakarta: Pustaka Panjimas,1996)

Muhammad Ali Al-Najjar, Mu'jam alfazal-Qur'an al-Karim, (Kairo: Mu'jam allugah al-Arabiyyah,1996)

Muhammad bin Ahmad Al-Anshari Al-Quthubi, Al-Jami' Li Ahkam Al-Quran (Tafsir Al-Qurthubi), vol 1, (Kairo: Maktabah Al-Iman, tt).

Proyek Pembibitan Calon Tenaga Kependidikan, Biro Kepegawaian Sekretariat Jendral, Departemen Agama Republik Indonesia" Petunjuk Teknis Pelaksanaan Jabatan Fungsional Penyuluh Agama dan Angka Kreditnya (Jakarta: Depag RI :2003)

Rif'at Mujahid Mutawaali, Manhaj ad-da'wah wa thuruq ad-du'aat (Kairo: Mathba, at al-azhar al-s yarif,1997)

Rumadi. Masyarakat Post-Teologi, (Bekasi: Gugus Press, 2002),

Suarajawatengah.id.senin 10 agustus 2020 / 05:05 Wib.

Syaikh Abdullah Bin Muhammad Menyingkap Hakekat Aqidah Syiah, (Jaringan Pembelaan Terhadap Sunnah.2015)

Syaikh Abd Al-Rahman Hasan Alu Syaikh, Fath Al-Majid syarh kitab Tawhid, terj. Oleh Abu da'in Hamzah (jakarta: Pustaka Azzam, 2002) Cet. Ke 1.

Syaikh idahram, Sejaharah Berdarah Sekte Salafi Wahabi, (Yogyakarta: Pustaka Pesantren 2013)

Sulaiman al-Khirasyi, Hakikat Liberaliyah wa mauqif Muslim minha, 112

Syamsuddin Arif, Orientalis dan Diabolisme Pemikiran, Jakarta: Gema Insani Press (GIP), Februari 2008,

Yusuf Al-Qaradhawi, al-sahwah al Islamiyah Bayna jumud wa al-Tatarruf, (Kairo: Dar-al-syuruq,2001) cet I 